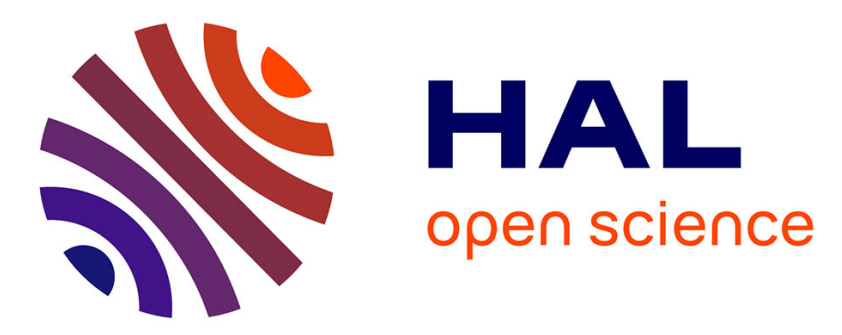

\title{
A Thiosemicarbazone-Nickel(II) Complex as Efficient Electrocatalyst for Hydrogen Evolution
}

Tatiana Straistari, Jennifer Fize, Sergiu Shova, Marius Réglier, Vincent Artero, Maylis Orio

\section{- To cite this version:}

Tatiana Straistari, Jennifer Fize, Sergiu Shova, Marius Réglier, Vincent Artero, et al.. A Thiosemicarbazone-Nickel(II) Complex as Efficient Electrocatalyst for Hydrogen Evolution. ChemCatChem, 2017, 10.1002/cctc.201600967 . hal-02191296

\section{HAL Id: hal-02191296 \\ https://hal.science/hal-02191296}

Submitted on 23 Jul 2019

HAL is a multi-disciplinary open access archive for the deposit and dissemination of scientific research documents, whether they are published or not. The documents may come from teaching and research institutions in France or abroad, or from public or private research centers.
L'archive ouverte pluridisciplinaire HAL, est destinée au dépôt et à la diffusion de documents scientifiques de niveau recherche, publiés ou non, émanant des établissements d'enseignement et de recherche français ou étrangers, des laboratoires publics ou privés. 


\title{
A thiosemicarbazone-nickel(II) complex as efficient electrocatalyst for hydrogen evolution
}

\author{
Tatiana Straistari, ${ }^{[\mathrm{a}, \mathrm{b}]}$ Jennifer Fize,${ }^{[\mathrm{c}]}$ Sergiu Shova, ${ }^{[\mathrm{d}]}$ Marius Réglier, ${ }^{[\mathrm{a}]}$ Vincent Artero ${ }^{\star[\mathrm{c}]}$ and Maylis \\ Orio*[a]
}

Dedicated in memory of Prof. Constantin Turta for his outstanding contribution to inorganic and coordination chemistry

\begin{abstract}
We report herein on of the synthesis and characterization of a new mononuclear nickel complex NiL based on a thiosemicarbazone ligand that exhibits an electrocatalytic behavior for $\mathrm{H}_{2}$ evolution in DMF using trifluoroacetic acid (TFA) as the proton source. A maximum turnover frequency $\left(\mathrm{TOF}_{\max }\right.$ ) of $3080 \mathrm{~s}^{-1}$ was extrapolated for $1 \mathrm{M}$ proton concentration using the foot-of-the wave analysis of cyclic voltammetry data. Gas analysis during controlled potential electrolysis experiments confirmed the catalytic nature of the process and production of dihydrogen with $80 \%$ faradaic yield. Quantum chemical calculations indicate that the catalytic mechanism involves first ligand-based reduction and protonation steps followed by metal-centered processes.
\end{abstract}

\section{Introduction}

Facing the $21^{\text {st }}$ century energy challenge, dihydrogen production as an alternative fuel by catalytic water splitting is a central theme in the field of renewable energy storage. ${ }^{[1]}$ Platinum possesses the best performances among catalysts able to reduce protons to dihydrogen. ${ }^{[2]}$ However, due to its scarcity and its cost, efforts to find alternative non-noble transition metal catalysts have been the subject of intense research. ${ }^{[3-6]}$ Inspiration by nature has often guided these researches. For example, some of us recently reported a heterobinuclear NiFe complex reproducing the structure of the active site of [NiFe]hydrogenase, ${ }^{[7]}$ and exhibiting high rates for electrocatalytic $\mathrm{H}_{2}$ evolution in mildly acidic solutions. ${ }^{[8]}$ Besides such biomimetic approaches, a number of molecular catalysts based on Earthabundant metals have been developed in the recent years and were benchmarked with the so-called "catalytic Tafel plots". ${ }^{[9]}$ Together with the introduction of proton relays in the second coordination sphere of the metal center, ${ }^{[10,11]}$ redox-active ligands $^{[12]}$ can be exploited to promote or enhance catalytic activity. ${ }^{[13-16]}$ Transition metal complexes with bis-

[a] T. Straistari, Dr. M. Réglier, Dr. M. Orio

Aix Marseille Univ, CNRS, Centrale Marseille, iSm2, Marseille,

France

E-mail: maylis.orio@univ-amu.fr

[b] T. Straistari

Institute of Chemistry, Academy of Sciences of Moldova

3, Academiei str., Chisinau MD 2028, Republic of Moldova

[c] J. Fize, Dr. V. Artero

Univ. Grenoble Alpes, CNRS UMR 5249, CEA, Laboratoire de

Chimie et Biologie des Métaux, 38000 Grenoble, France

E-mail: vincent.artero@cea.fr

[d] Dr. S. Shova

Institute of Macromolecular Chemistry "Petru Poni", 41A Grigore

Ghica Voda Alley, Iasi-700487, Romania thiosemicarbazone ligands have been studied for many years. ${ }^{[17]}$ Beyond their interest as chemotherapeutics or radiopharmaceutics, ${ }^{[18]}$ these complexes present some interesting features (redox properties, nitrogen or sulfur atoms as potential proton relays) that could be relevant for electrocatalytic proton reduction. Recently, Haddad et al. have reported a bis-thiosemicarbazone zinc complex that functions as a homogeneous electrocatalyst for proton reduction, ${ }^{[16]}$ and analyzed its reactivity in terms of ligand-centered ${ }^{[15][19,20]}$ protontransfer and electron-transfer processes shortcutting traditional metal-hydride intermediates. In that perspective, we associated the electroactive bis-thiosemicarbazone ligand with redox-active transition metal and report here the synthesis and characterization of a bis-thiosemicarbazone nickel(II) complex together with its evaluation as an electrocatalyst for proton reduction.

\section{Results and Discussion}

\section{Synthesis of the ligand and complex}

The 4-\{bis(4-(p-methoxyphenyl)-thiosemicarbazone)\}-2,3butane ligand $\left(\mathrm{H}_{2} \mathrm{~L}\right)$ used in this study was quantitatively prepared by the reaction of 2,3-dihydrazide-butane with two equivalents of 1 -isothiocyanato-4-methoxy-benzene in refluxing ethanol. $\mathbf{H}_{2} \mathbf{L}$ precipitated from ethanol as a yellow-orange powder in $93 \%$ yield and was used further without any additional purification, except washing with ethanol. The addition of one equivalent of nickel nitrate to a suspension of $\mathbf{H}_{2} \mathrm{~L}$ in methanol, resulted in the formation of the NiL nickel complex in good yield (65\%). The crude compound precipitated as a dark brown microcrystalline powder and did not required any purification, except washing with methanol. $\mathbf{H}_{2} \mathbf{L}$ and $\mathrm{NiL}$ were fully characterized by elemental analyses, infra-red and ${ }^{1} \mathrm{H}$ NMR spectroscopies and their structures were confirmed by $\mathrm{X}$-ray crystallography.

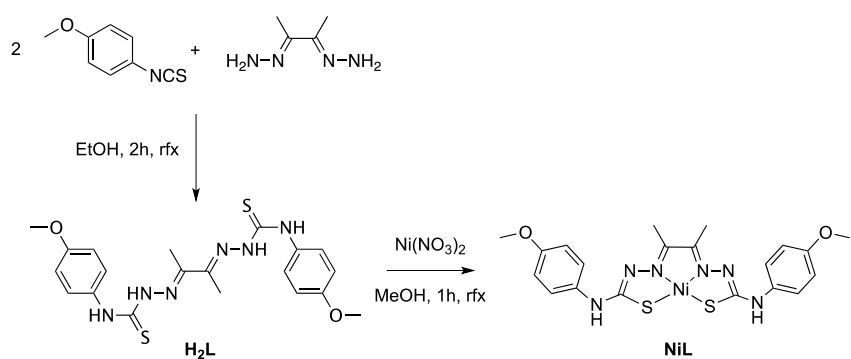

Scheme 1. Synthesis of $H_{2} L$ and NiL. 


\section{X-ray Crystallography}

Crystals of $\mathbf{H}_{2} \mathrm{~L}$, [NiL]-2.5DMF and [NiL].2DMSO compounds suitable for $X$-ray analysis were grown from DMF. $\mathbf{H}_{2} \mathbf{L}$ crystallizes in triclinic $P-1$ space group and its structure consists of $\quad 4-\{$ bis (4-(p-methoxyphenyl)-thiosemicarbazone) $\}-2,3-$ butane molecule (Figure SI-1 and SI-2) as the asymmetric part of the unit cell. The results of single crystal X-ray study for [NiL] 2.5DMF and [NiL].2DMSO complexes are shown in Figures 1 and SI-3, respectively. Since both complexes exhibit similar molecular structures (Table SI-1), only the crystal structure of [NiL]-2.5DMF will be described. The assymmetric unit contains two crystallographically distinct but chemically identical NiL neutral complexes (denoted A and B) and 5 DMSO as solvated molecules. Each $\mathrm{Ni}$ atom has a distorted square-planar $\mathrm{N}_{2} \mathrm{~S}_{2}$ coordination geometry provided by tetradentate doubly deprotonated ligand $\mathrm{L}^{2-}$. Both $\mathrm{NiN}_{2} \mathrm{~S}_{2}$ fragments are essentially planar within 0.003 and $0.002 \AA$ distortion for $\mathrm{A}$ and $\mathrm{B}$ molecules respectively. As a whole, both independent NiL units are also almost planar being arranged in parallel fashion with an interplanar angle of $1.33^{\circ}$. Selected bond lengths are provided in the caption of Figure 1.

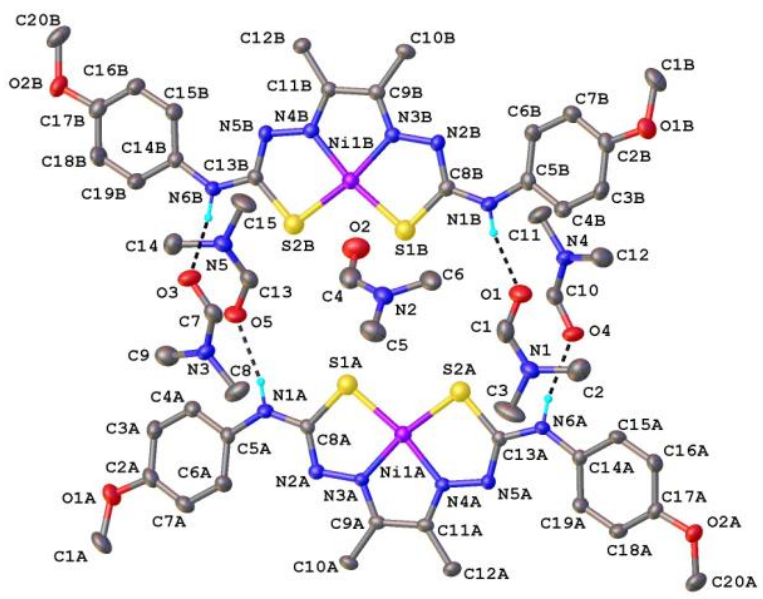

Figure 1. Asymmetric part in the crystal structure of [NiL]-2.5DMF with atom labeling scheme and ellipsoids parameters at $50 \%$ probability level. $\mathrm{H}$-atoms not involved in hydrogen bonds are omitted for clarity. Selected bond lengths: $\mathrm{Ni}(1 \mathrm{~B})-\mathrm{S}(1 \mathrm{~B}) 2.170(4) \AA, \mathrm{Ni}(1 \mathrm{~B})-\mathrm{S}(2 \mathrm{~B}) 2.167(4) \AA, \mathrm{Ni}(1 \mathrm{~B})-\mathrm{N}(3 \mathrm{~B}) 1.80(1)$ $\AA, N i(1 B)-N(4 B) 1.85(1) \AA, N i(1 A)-S(1 A) 2.165(5) \AA, N i(1 A)-S(2 A)$ 2.170(5) $\AA, N i(1 A)-N(3 A) 1.82(1) \AA, N i(1 A)-N(4 A) 1.84(2) \AA$. Hydrogen

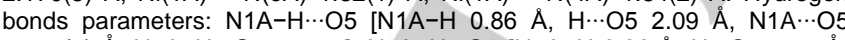

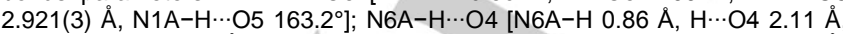
$\mathrm{N} 6 \mathrm{~A} \cdots \mathrm{O} 42.932(3) \AA$

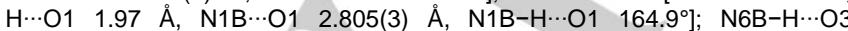

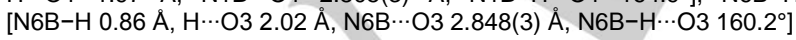

\section{Electrochemical Studies}

Cyclic voltammograms $(\mathrm{CV})$ were recorded at a glassy carbon electrode in anhydrous DMF in the presence of $0.1 \mathrm{M} \mathrm{NBu}_{4} \mathrm{PF}_{6}$ as supporting electrolyte. Potentials are referred to a $\mathrm{Ag} / \mathrm{AgCl}$ reference electrode. The redox behavior of $\mathbf{H}_{2} \mathrm{~L}$ was investigated first. In the potential range between +0.8 and $-2.0 \mathrm{~V}$ vs $\mathrm{Ag} / \mathrm{AgCl}$, the $\mathrm{CV}$ of $\mathrm{H}_{2} \mathrm{~L}$ and its deprotonated form $\mathrm{L}^{2-}$, formed in situ through reaction with $\mathrm{Et}_{3} \mathrm{~N}$,revealed no oxidative processes, while an irreversible wave corresponding to the reduction of the imine functions is observed at $-1.65 \mathrm{~V}$ vs $\mathrm{Ag} / \mathrm{AgCl}$ (Figure SI4). ${ }^{[21]}$ This wave is more intense in the deprotonated ligand. To study the behavior of the ligand in acid medium, we recorded successive cyclic voltammograms of $\mathbf{H}_{2} \mathrm{~L}$ in DMF in the presence of trifluoroacetic acid. Scans in the negative direction from 0 to $-2 \mathrm{~V}$ vs $\mathrm{Ag} / \mathrm{AgCl}$ revealed no catalytic wave

Figure 2 shows the CV of NiL in anhydrous DMF under argon. It revealed two successive reversible one-electron redox systems at $-1.04 \mathrm{~V}\left(\left(E_{\mathrm{pc}}{ }^{*}+E_{\mathrm{pa}}{ }^{*}\right) / 2\right)$ and $-1.67 \mathrm{~V}$ vs $\mathrm{Ag} / \mathrm{AgCl}\left(\left(E_{\mathrm{pc}}{ }^{* \star}+\right.\right.$ $\left.\left.E_{\mathrm{pa}}{ }^{* *}\right) / 2\right)$.

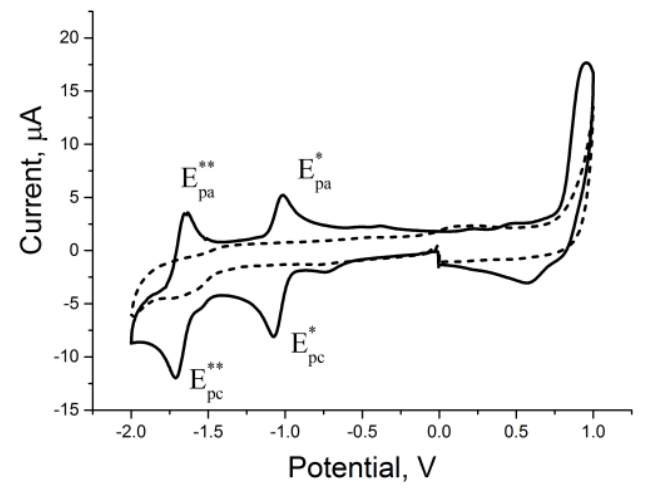

Figure 2. Cyclic voltammograms of $\mathbf{H}_{2} \mathbf{L}$ (black dashed line) and NiL (black plain line), (1 $\mathrm{mM}$ ) at a stationary glassy carbon electrode in $\mathrm{DMF}+0.1 \mathrm{M}$ $\mathrm{NBu}_{4} \mathrm{PF}_{6}$. Scan rate $500 \mathrm{mV} / \mathrm{s}$. Potentials are referenced to the $\mathrm{Ag} / \mathrm{AgCl}$ electrode

A plot of the current peaks versus the square root of the scan rates for both waves is linear, indicating that is a diffusioncontrolled process (Figure SI-5). In an effort to understand the redox behavior of NiL, DFT calculations were undertaken. The structures of $\mathrm{NiL}, \mathrm{NiL}^{-}$and $\mathrm{NiL}^{2-}$ were subjected to geometry optimization (Figure $\mathrm{SI}-9$ ) and their electronic structures were investigated (Figures 3 and SI-10). Comparison of the DFToptimized structure of NiL with the X-ray data showed a pretty good agreement between the two sets of data which confirmed that $\mathrm{NiL}$ can be best described as a low spin $\mathrm{Ni}$ (II) complex $\left(\left[\mathrm{Ni} \mathrm{L}^{\mathrm{Il}}\right]^{0}, \mathrm{~S}=0\right)$. Looking at the one-electron reduced species, a delocalized ligand-based radical species ([Ni"L'], $S=1 / 2$ ) is formed upon reduction of NiL as the singly occupied molecular orbital (SOMO) of $\mathrm{NiL}^{-}$is essentially distributed over the hydrazone bridge of the complex. The second reduction process in NiL occurs at the metal site leading to the formation of $\mathrm{Ni}(\mathrm{I})$ as the second SOMO of $\mathrm{NiL}^{2-}$ is mainly distributed on the nickel center and its coordinating atoms. Due to the orthogonality of the two SOMOs of $\mathrm{NiL}^{2-}$ and an energy gap of $25 \mathrm{kcal}^{2} \mathrm{~mol}^{-1}$ with respect to the singlet state, the ground spin state of this species can be assigned as a triplet $\left(\left[\mathrm{Ni}^{\prime} \mathrm{L}^{\circ}\right]^{2-}, \mathrm{S}=1\right.$ ) (See the supporting information). These data thus support the experimental assignment of the reduction loci in NiL. 
NiL $\left(\left[N i^{\prime \prime}\right]^{0}, S=0\right)$

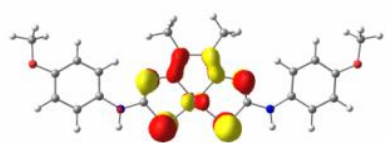

HOMO

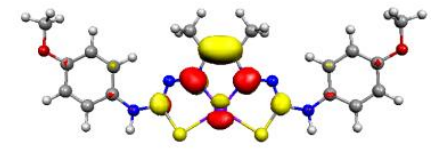

SOMO

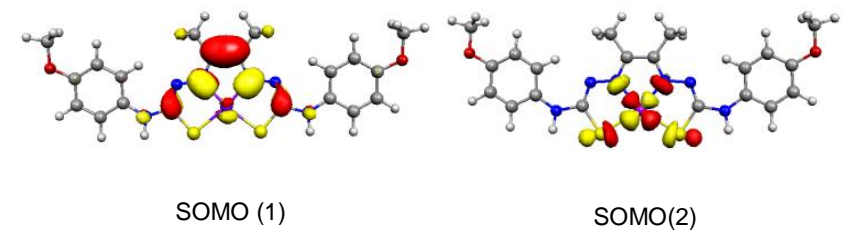

Figure 3. DFT-calculated redox active orbitals for neutral, mono and direduced species of $\mathrm{NiL}$.

\section{UV-Visible Spectroscopy and Spectroelectrochemistry}

UV/Vis absorption spectra recorded in DMF for NiL complex exhibit an intense band at $\lambda_{\max }=470 \mathrm{~nm}(\varepsilon=17000$, Figure 4). The electrochemical reduction of $\mathrm{NiL}$, at room temperature was monitored spectro-electrochemically using an optically transparent electrode under $\mathrm{Ar}$ in DMF containing $\mathrm{NBu}_{4} \mathrm{PF}_{6}(0.1$ M) as supporting electrolyte. After applying the potential of the first reduction band $\left(E_{\mathrm{pc}}{ }^{*}\right)$, we observed a slight decrease in intensity of the band associated with the NiL complex (green line), and after further electrochemical re-oxidation $\left(E_{\mathrm{pa}}{ }^{*}\right)$, the band returned to the original shape (red line). Strong decrease in intensity of the band is observed after second electrochemical reduction $\left(E_{\mathrm{pc}}{ }^{* *}\right.$, blue line). After total electrochemical reoxidation $\left(E_{\mathrm{pa}}{ }^{*}\right)$, the intensity of the band returned to the initial one. This behavior strongly confirms the reversibility of the redox electrochemical processes.
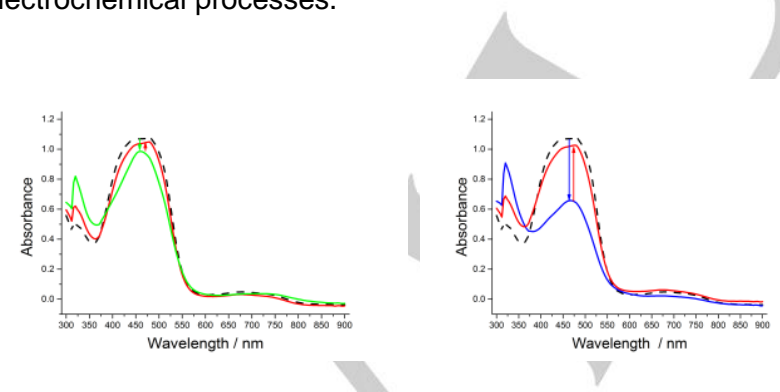

Figure 4. Electronic absorption spectra for NiL (black dash), one-electron reduced specie $\mathrm{NiL}^{-}$(green line), two-electron reduced species $\mathrm{NiL}^{2-}$ (blue line), and electrochemical re-oxidized species (red lines).

TDDFT calculations performed on neutral, mono and di-reduced forms of NiL further supported that the UV-vis spectrum of the complex is dominated by one main absorption band in all three redox states. This band could be assigned to (i) a mixed metalligand to metal-ligand transition for NiL; (ii) a metal to ligand transition in $\mathrm{NiL}^{-}$and (iii) to a ligand-to-ligand charge transfer in $\mathrm{NiL}^{2-}$ (Table SI-3 and Figure SI-12). Our calculations also show a decrease in the intensity of the band for the direduced compound, consistently with the experimental observation (Figure SI-11).

\section{Electrocatalysis}

To examine the capability of NiL to mediate proton reduction catalysis, we investigated its electrochemical response in the presence of trifluoroacetic acid (TFA, $\mathrm{pK} K_{a}=6.0 \pm 0.3$ in DMF) ${ }^{[22]}$ as a protons source. Cyclic voltammograms of NiL recorded in DMF with increasing concentration of TFA are shown in Figure SI-6. A large irreversible catalytic wave starting at about -0.70 $\mathrm{V}$ vs. $\mathrm{Ag} / \mathrm{AgCl}$ is observed. The current response of this irreversible cathodic wave is directly proportional to the concentration of protons in the electrolyte solution while the peak maximum is gradually shifted of from -1.57 to $-1.77 \mathrm{~V}$ vs $\mathrm{Ag} / \mathrm{AgCl}$. Comparison with a control experiment measured in the absence of NiL demonstrate the catalytic effect of the nickel complex.. The wave displays several shoulders indicative several mechanisms operating at different potentials. We only investigate here the process occurring at more positive potentials with a mid-wave potential $\left(E_{c a t}^{0}\right)$ of $-0.8 \mathrm{~V} v \mathrm{Ag} / \mathrm{AgCl}$, (Figure 5).
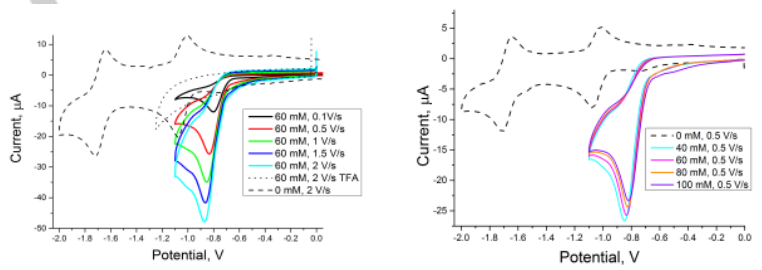

Figure 5. Successive cyclic voltammograms recorded at a glassy carbon electrode of a $1 \mathrm{mM}$ solution of NiL complex in DMF ( $\left.0.1 \mathrm{M} \mathrm{NBu}_{4} \mathrm{PF}_{6}\right)$ with 60 mM TFA at 5 different scan rates (left) and increasing concentration of TFA at $500 \mathrm{mV} / \mathrm{s}$ scan rate (right). Potentials are referenced to the $\mathrm{Ag} / \mathrm{AgCl}$ electrode.

\section{Bulk electrolysis and gas analysis}

To confirm that the catalytic wave corresponds to the reduction of protons to molecular hydrogen, we performed a bulk electrolysis experiment on a mercury pool electrode in DMF in the presence of TFA. This experiment was coupled with in-line $\mathrm{GC}$ analysis. During a $16 \mathrm{~h}$ electrolysis experiment of a $1 \mathrm{mM}$ NiL DMF solution $\left(0.1 \mathrm{M} \mathrm{NBu}_{4} \mathrm{PF}_{6}, 8 \mathrm{~mL}\right)$ added with $100 \mathrm{mM}$ TFA at $-1.2 \mathrm{~V} v \mathrm{vs}$. $\mathrm{Ag} / \mathrm{AgCl}$, hydrogen was produced with $80 \%$ faradaic efficiency and a turnover number of 21 (Figure SI-8). A control experiment performed in the absence of NiL produced significantly less hydrogen (Figure SI-6). These experiments allow to rule out the possibility that proton reduction occurs as the result of deposition of nickel nanoparticles on the electrode surface since they would amalgamate within the mercury pool electrode.

\section{Kinetic analysis and benchmarking of performances}


The foot-of-the-wave analysis (FOWA) was used to quantify the rates of the hydrogen evolution reaction from $\mathrm{CV}$ measurements. ${ }^{[9,23]}$

Plotting $i / i_{P}^{0}$ (with $i_{P}^{0}$ being the peak current of a monoelectronic wave measured in the absence of acid) as a function of $1 /(1+$ $\exp F / R T E-E c a t O$ near the foot of the wave gave a linear function at a given scan rate. The observed rate constant $k_{\text {cat }}$ can be extracted from the slope of the linear fit, considering the formula corresponding to an ECEC mechanism (E corresponds to an electron transfer step and $C$ to a chemical reaction, here protonation) as shown in Scheme 2 (see below). The rate constant $\mathrm{k}_{\text {cat }}$ for $\mathrm{H}_{2}$ evolution catalyzed by NiL was determined for 4 TFA concentrations $(10,30,60$ and $80 \mathrm{mM})$ at 4 different scan rates in the $0.5-2 \mathrm{~V} / \mathrm{s}$ range. Our data indicated that $\mathrm{k}_{\text {cat }}$ was proportional to the acid concentration $\left(k_{c a t}=k_{o b s} \times\left[\mathrm{H}^{+}\right]\right.$ with $k_{o b s}$ the rate constant for the rate-determining step of the process and $\left[\mathrm{H}^{+}\right]$the concentration of the acid in the bulk solution (Table SI-2). An average value of $k_{\text {obs }}=3080 \mathrm{M}^{-1} \mathrm{~s}^{-1}$ (Figure SI-7) was obtained. From that value a turnover frequency of $3080 \mathrm{~s}^{-1}$ can be extrapolated for $1 \mathrm{M}$ acid concentration. Based on this value, the $E_{\text {cat }}^{0}$ value of $-0.8 \mathrm{~V}$ vs $\mathrm{Ag} / \mathrm{AgCl}$ (corresponding to $-1.33 \mathrm{~V}$ vs $\mathrm{Fc}^{+} / \mathrm{Fc}$ ) and an apparent equilibrium potential of the $\mathrm{H}^{+} / \mathrm{H}_{2}$ couple $\left(-1.01 \mathrm{~V} \mathrm{vs} \mathrm{Fc}^{+} / \mathrm{Fc}^{[24]}\right)$ at 1M TFA concentration, we could derive the bold magenta trace in the catalytic Tafel plot shown in Figure 6, relating the turnover frequency and driving force of the reaction, that is, the overpotential related to $\mathrm{H}_{2}$ evolution under the conditions used. ${ }^{[9}$, 25] Although not rivalling nickel-bisdiphosphine or cobaloxime catalysts, NiL complex displays significant catalytic activity $(\log (\mathrm{TOF}) / \mathrm{s}-1)>1)$ for overpotential values slightly lower than iron tetraphenylporphyrin ${ }^{[9]}$.

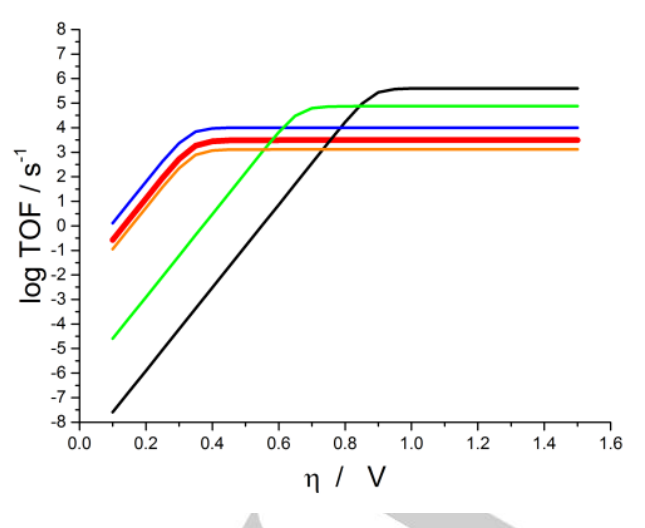

Figure 6. Catalytic Tafel plots. Comparison of performances for hydrogen evolution catalyzed by NiL in DMF in presence of 1 M TFA (magenta line) with those of other catalysts reported in the literature. Black: Fe"TPP, DMF, $\mathrm{Et}_{3} \mathrm{NH}^{+}$. Blue: $\mathrm{Co}^{\prime \prime}(\mathrm{dmgH})_{2} \mathrm{py}, \mathrm{DMF}, \mathrm{Et}_{3} \mathrm{NH}^{+}$. Green: $\left[\mathrm{Ni}\left(\mathrm{P}_{2}{ }^{\mathrm{Ph}} \mathrm{N}^{\mathrm{Ph}}\right)_{2}\right]^{2+}, \mathrm{MeCN}, \mathrm{DMFH}^{+}$. Orange: $\left[\mathrm{Ni}^{\prime \prime}\left(\mathrm{P}_{2}{ }^{\mathrm{Ph}} \mathrm{N}_{2}{ }^{\mathrm{C} 6 \mathrm{H} 4 \mathrm{X}}\right)_{2}\right]^{2+}, \mathrm{X}=\mathrm{CH}_{2} \mathrm{P}(\mathrm{O})(\mathrm{OEt})_{2}, \mathrm{MeCN}, \mathrm{DMFH}^{+}$. Red : $\left[\mathrm{Ni}^{\prime \prime}\left(\mathrm{P}_{2}^{\mathrm{Ph}} \mathrm{N}_{2}{ }^{\mathrm{C} 6 \mathrm{H} 4 \mathrm{X}}\right)_{2}\right]^{2+}, \mathrm{X}=\mathrm{H}, \mathrm{MeCN}, \mathrm{TfOH}$. .

\section{Mechanistic considerations}

To gain more insight on the locus of proton addition following the electrochemical reduction process, we have conducted additional DFT calculations. For this purpose, we have considered five potential sites for the addition of one proton on the one-electron reduced species $\mathrm{NiL}^{-}$: the metal center $[\mathrm{Ni}-\mathrm{H}]^{-}$, the sulfur atom (generating $[\mathrm{Ni}-\mathrm{SH}]^{-}$), the nitrogen atom from the hydrazone group (generating $\left.[\mathrm{Ni}-\mathrm{HN}]^{-}\right)$, the internal nitrogen atom from the thiosemicarbazone motif (generating $[\mathrm{Ni}-\mathrm{NH}]^{-}$) and the nitrogen atom from the phenylthiocarbamide fragment (generating $[\mathrm{Ni}-\mathrm{HNH}]$ ) (Figures $\mathrm{SI}-13$ and $\mathrm{SI}-15$ to $\mathrm{SI}-18$ ). Our results clearly pinpoint that the hydrazine-nitrogen is the preferential locus and can be best described as a ligand-based radical species (Figure SI-14). Indeed, the calculated free energies for the five forms predict the $[\mathrm{Ni}-\mathrm{HN}]^{-}$form to be lower in energy by $4.0,12.3,18$ and $21.3 \mathrm{kcal} / \mathrm{mol}^{-1}$ than the $[\mathrm{Ni}-\mathrm{NH}]^{-}$, $[\mathrm{Ni}-\mathrm{HNH}]^{-},[\mathrm{Ni}-\mathrm{SH}]^{-}$and $[\mathrm{Ni}-\mathrm{H}]^{-}$ones, respectively (Figure 7). The preferential locus for the successive reduction of the oneelectron protonated species was also investigated (Figures SI20 and SI-22 to SI-25) and the theoretical data show that the favored species is the di-reduced $[\mathrm{Ni}-\mathrm{HN}]^{2-}$ complex (Figure SI19). Our calculations also indicate that this reduction is a metalbased process as positive spin population is found at the $\mathrm{Ni}$ center (Figure SI-21). This would support the metal as being the preferential locus for the second protonation of $[\mathrm{Ni}-\mathrm{HN}]^{2-}$,

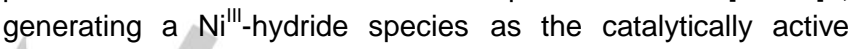
species responsible for $\mathrm{H}_{2}$ evolution.

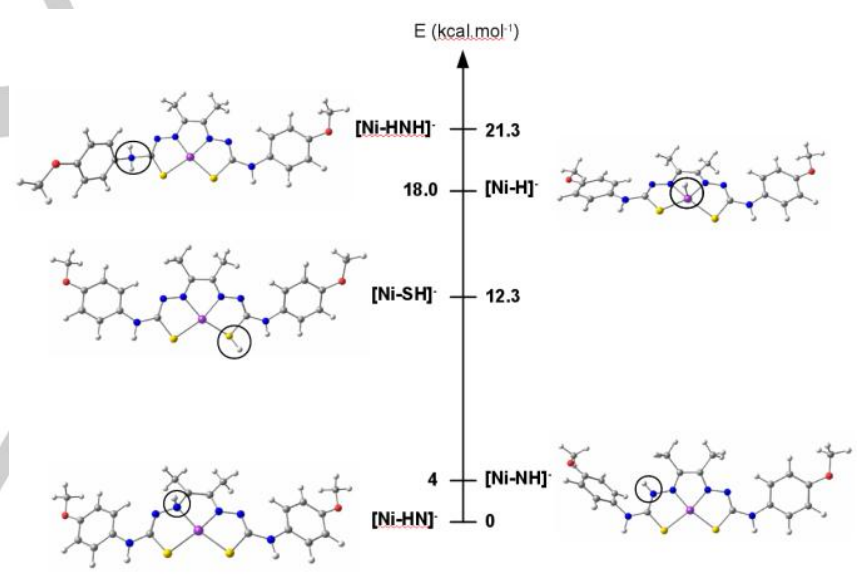

Figure 7. Energetic stability of protonated species of $\mathrm{NiL}^{-}$

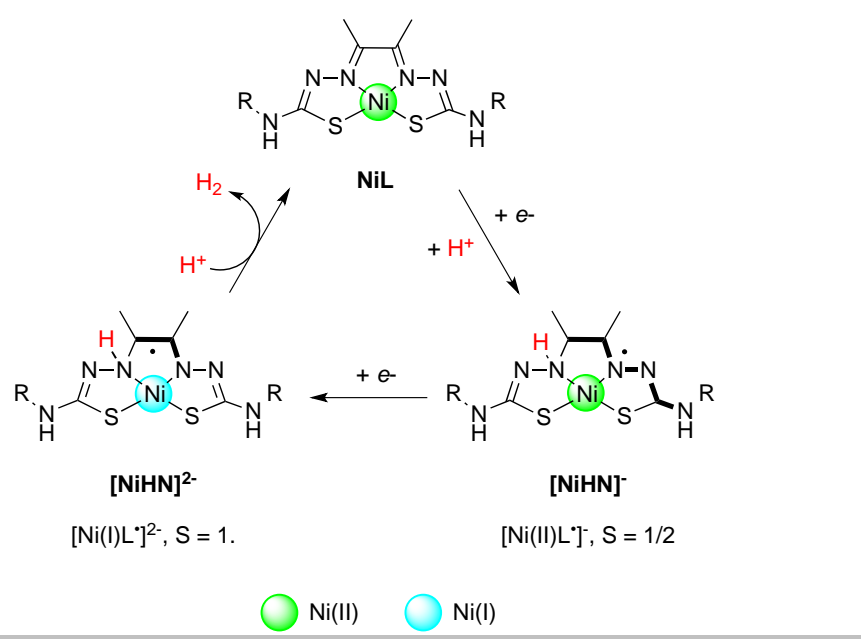


Scheme 2. Proposed mechanism for $\mathrm{H}_{2}$ evolution.

\section{Conclusions}

In summary, we have shown that the mononuclear nickel complex NiL with bis-thiosemicabazone ligand exhibits a high electrocatalytic activity for proton reduction to dihydrogen. The benchmarking of the performances of NiL was achieved through foot-of-the-wave analysis ${ }^{[9]}$ leading to a maximum turnover frequency $3080 \mathrm{~s}^{-1}\left(\mathrm{TOF}_{\max }\right)$ placing NiL among the best catalyst reported in the literature in catalytic Tafel plots. With the help of DFT calculations, we could proposed a mechanism involving two steps: 1) the protonation of the $\mathrm{N}$-atom from the hydrazone function of a mono-reduced species and 2) a second reduction associated with a nickel centred protonation for subsequent hydrogen evolution.

Recently; Grapperhaus and coworkers reported a bisthiosemicabazone zinc complex capable of electrocatalytic proton reduction through a process entirely centered on the ligand, ${ }^{[16]}$ i.e. without any occurrence of a zinc hydride species. This was confirmed by the activity of the ligand alone, which exhibits a quite high TOF $\left(1320 \mathrm{~s}^{-1}\right)$ compared to the zinc complex $\left(1170 \mathrm{~s}^{-1}\right)$. Grapperhaus and colleagues argued that in transition-metal complexes, spin-orbit coupling between ligandbased radical and unpaired electrons from the metal can reduce reactivity. Our ligand $\mathrm{L}^{2-}$ appears to be deprived of any catalytic activity for $\mathrm{H}_{2}$ evolution. With a TOF $\mathrm{Tax}_{\max }$ of $3080 \mathrm{~s}^{-1}$ for NiL, our results however confirm the interest to combine electroactive ligand such as bis-thiosemicarbazone with a transition metal ion to obtain a synergistic effect with both redox moieties.

\section{Experimental Section}

All solvents and chemicals were purchased from Sigma Aldrich and used without further purification. Syntheses of 1-isothiocyanato-4-methoxybenzene and 2,3-dihydrazide-butane were performed according to procedures described by Demchenko ${ }^{[26]}$ and Lakshmi. ${ }^{[27]}$ The synthesis of the ligand $\mathrm{H}_{2} \mathrm{~L}$ is presented in ESI. ${ }^{1} \mathrm{H}$ NMR spectra were recorded on Bruker $400 \mathrm{MHz}$ Avance III nanobay. Chemical shifts for ${ }^{1} \mathrm{H}$ NMR spectra are referenced relative to TMS or the residual protonated solvent. IR spectra were recorded with Bruker TENSOR 27 spectrometer equipped with a single-reflection DuraSamplIR diamond. Elemental analysis was performed on Thermo Finnigan EA 1112 instrument. The results were validated by at least two sets of measurements.

\section{Synthesis of $\mathrm{H}_{2} \mathrm{~L}$}

Synthesis of 4-\{bis(4-(p-methoxyphenyl)-thiosemicarbazone)\}-butane ligand $\left(\mathrm{H}_{2} \mathrm{~L}\right)$. The 2,3-dihydrazide-butane $(4.382 \mathrm{mmol} ; 0.5 \mathrm{~g})$ was dissolved in ethanol $(20 \mathrm{ml})$, and then added dropwise to two equivalents of 1-isothiocyanato-4-methoxy-benzene solution in ethanol $(10 \mathrm{ml})$. The mixture was heated at reflux for $2 \mathrm{~h}$. After the reaction mixture was cooled to room temperature, the yellow solid was filtered and washed with two portions of ethanol to give $93 \%$ yield of crude compound that was used for the complexation step whitout additional purification. Selected data for ligand: ${ }^{1} \mathrm{H}$ NMR $\left(400 \mathrm{MHz},\left[\mathrm{D}_{6}\right] \mathrm{DMSO}, \mathrm{TMS}\right): \delta=10.55$ (s, 2H; NH), $9.89(\mathrm{~s}, 2 \mathrm{H} ; \mathrm{NH}), 7.38(\mathrm{~d}, J=9 \mathrm{~Hz}, 4 \mathrm{H} ; o-\mathrm{CH}), 6.93(\mathrm{~d}, J=9$ $\mathrm{Hz}, 4 \mathrm{H} ; p-\mathrm{CH}), 3.76$ (s, $\left.6 \mathrm{H} ; \mathrm{O}-\mathrm{CH}_{3}\right), 2.30$ ppm (s, $\left.6 \mathrm{H} ; \mathrm{CH}_{3}\right)$. FT-IR: 3209
$\mathrm{cm}^{-1}(\mathrm{~N}-\mathrm{H}), 1593 \mathrm{~cm}^{-1}\left(\mathrm{C}=\mathrm{N}\right.$ imine), $1510(\mathrm{~N}-\mathrm{C}) \mathrm{cm}^{-1}, 1240 \mathrm{~cm}^{-1}$ and $1026 \mathrm{~cm}^{-1}(\mathrm{O}-\mathrm{C}), 829 \mathrm{~cm}^{-1}(\mathrm{C}=\mathrm{S})$. Elemental analysis: calcd. (\%) for $\mathrm{C}_{20} \mathrm{H}_{24} \mathrm{~N}_{6} \mathrm{O}_{2} \mathrm{~S}_{2}$ (444.57): C 54.03, H 5.44, N 18.90, S 14.43; found: C $54.10, \mathrm{H} 5.37, \mathrm{~N} 18.89$, S 14.36

\section{Synthesis of NiL}

To the suspension of ligand $\mathbf{H}_{2} \mathrm{~L}(0.225 \mathrm{mmol}, 0.1 \mathrm{~g})$ in methanol $(5 \mathrm{ml})$, wad added drop-wise one equivalent of $\mathrm{Ni}\left(\mathrm{NO}_{3}\right)_{2}\left(\mathrm{H}_{2} \mathrm{O}\right)_{6}(0.225 \mathrm{mmol}$, $0.065 \mathrm{~g}$ ) solution in methanol $(2 \mathrm{ml})$. The resulting suspension was stirred at reflux for 2 hours. The resulting precipitate was filtrated and washed with methanol. Single crystals suitable for crystallographic analysis were grown from DMF solution with $65 \%$ yield. Selected data: ${ }^{1} \mathrm{H}$ NMR $(400$ $\mathrm{MHz},\left[\mathrm{D}_{6}\right]$ DMSO-d 6 , TMS): $\delta=9.93(\mathrm{~s}, 2 \mathrm{H} ; \mathrm{NH}), 7.51(\mathrm{~d}, J=8.7 \mathrm{~Hz}, 4 \mathrm{H}$; $o-\mathrm{CH}), 6.87$ (d, $J=8.7 \mathrm{~Hz}, 4 \mathrm{H} ; p-\mathrm{CH}), 3.71\left(\mathrm{~s}, 6 \mathrm{H} ; \mathrm{O}-\mathrm{CH}_{3}\right), 2.04 \mathrm{ppm}$ (s, $\left.6 \mathrm{H} ; \mathrm{CH}_{3}\right)$;); FT-IR $3300 \mathrm{~cm}^{-1}(\mathrm{~N}-\mathrm{H}), 1600 \mathrm{~cm}^{-1}$ (C=N imine), $1504 \mathrm{~cm}^{-1}$ $(\mathrm{N}-\mathrm{C}), 1240 \mathrm{~cm}^{-1}$ and $1015 \mathrm{~cm}^{-1}(\mathrm{O}-\mathrm{C}), 817 \mathrm{~cm}^{-1}$ (C-S); elemental analysis. Calcd. $\mathrm{C}_{20} \mathrm{H}_{24} \mathrm{~N}_{6} \mathrm{O}_{2} \mathrm{~S}_{2} \mathrm{Ni}$ (501.25): C 47.92, H 4.42, N 16.77, S 12.79; found C 47.49, H 4.46, N 16.43, S 11.42 .

\section{X-ray crystallography}

Crystallographic data for $\mathbf{H}_{2} \mathbf{L}$ (CCDC-1497213), [NiL]-2.5DMF (CCDC 1497214) and [NiL]-2DMSO (CCDC-1497215) can be obtained free of charge from The Cambridge Crystallographic Data Centre via: www.ccdc.cam.ac.uk/data request/cif. The molecule of ligand has antispatial orientations towards the substituents in the butane unity. The thiosemicarbazone substituents are oriented head to head in approximately of $180^{\circ}$. The dihedral angles between $\mathrm{C} 14 / \mathrm{C} 19$ and C2/C6 aromatic rings and almost planar bis-thiosemicarbazone-2,3-butane fragment are of $17.01(7)^{\circ}$ and $64.68(6)^{\circ}$, respectively. In the crystal the adjacent neutral molecules $\mathrm{H}_{2} \mathrm{~L}$ are interacting through $\mathrm{N}-\mathrm{H} \cdots \mathrm{S}$ hydrogen bonds to form supramolecular chains in parallel orientation along $b$ crystallographic axis (Figure SI-2).

\section{Electrochemistry}

Cyclic voltammetry experiments were performed using a BioLogic SP300 potentiostat and a three-electrode set-up consisting of a glassy carbon working electrode, a platinum wire counter electrode and an $\mathrm{Ag} / \mathrm{AgCl}$ $(\mathrm{KCl} 3 \mathrm{M})$ reference electrode. Ferrocene was used as an interna standard with $\mathrm{E}^{0}\left(\mathrm{Fc}^{+} / \mathrm{Fc}\right)=0.53 \mathrm{~V}$ vs $\mathrm{Ag} / \mathrm{AgCl}$. All studies were performed in deoxygenated DMF containing $\mathrm{NBu}_{4} \mathrm{PF}_{6}(0.1 \mathrm{M})$ as supporting electrolyte. Controlled potential electrolysis experiments were carried out in two-compartment cell. The volume of solution (DMF, $0.1 \mathrm{M} \mathrm{NBu}_{4} \mathrm{PF}_{6}$ ) used in the working compartment of the cell was $8 \mathrm{ml}$. The working electrode used was a pool of mercury, separated from the coiled platinum wire counter electrode by a porous frit. Bulk electrolysis solutions were purged witch $\mathrm{N}_{2}$ gas for at least 20 min prior to electrolysis and stirred throughout bulk electrolysis experiment. During the experiment, the cell was continuously purged with nitrogen $\left(5 \mathrm{~mL} \cdot \mathrm{min}^{-1}\right)$ and the output gas was analyzed at two-minute intervals in a Perkin Elmer Clarus 500 gas chromatographer using a previously described setup $^{[28]}$.

\section{DFT calculations}

All theoretical calculations were performed with the ORCA program package. ${ }^{[29]}$ Full geometry optimizations were undertaken for all complexes using the GGA functional $\mathrm{BP}^{8} 6^{[30]}$ in combination with the $\mathrm{TZV} / \mathrm{P}^{[31]}$ basis set for all atoms, and by taking advantage of the resolution of the identity (RI) approximation in the Split-RI-J variant ${ }^{[32]}$ with the appropriate Coulomb fitting sets ${ }^{[33]}$ Increased integration grids (Grid4 in ORCA convention) and tight SCF convergence criteria were 
used. Electronic structures and Molecular Orbital diagrams were obtained from single-point calculations using the hybrid functional B3LYP ${ }^{[34]}$ together with the $\mathrm{TZV} / \mathrm{P}^{[31]}$ basis set. Increased integration grids (Grid4 and GridX4 in ORCA convention) and tight SCF convergence criteria were used in the calculations. For according to the experimental conditions solvent effects were accounted and we used the DMF solvent $(\varepsilon=37)$ within the framework of the conductor-like screening (COSMO) dielectric continuum approach. ${ }^{[35]}$ The relative energies were computed from the gas-phase optimized structures as a sum of electronic energy, solvation and thermal corrections to the free energy. Optical properties were predicted from additional single-point calculations using the hybrid functional B3LYP ${ }^{[34]}$ together with the $\mathrm{TZV} / \mathrm{P}^{[31]}$ basis set. Electronic transition energies and dipole moments for all models were calculated using time-dependent DFT (TD-DFT) ${ }^{[36]}$ within the Tamm-Dancoff approximation. ${ }^{[37]}$ To increase computational efficiency, the $\mathrm{RI}$ approximation ${ }^{[38]}$ was used in calculating the Coulomb term, and at least 30 excited states were calculated in each case. For each transition, difference density plots were generated using the orca plot utility program and were visualized with the Chemcraft program. ${ }^{[39]}$

\section{Acknowledgements}

The authors gratefully acknowledge the support of this work by the CNRS and the Academy of Sciences of Moldova (Bilateral agreement EDC25722 2013-2014), the French National Research Agency (Labex program, ARCANE, ANR-11-LABX0003-01); the COST Actions CM1305 ECOSTBio (Explicit Control Over Spin-States in Technology and Biochemistry) and $\mathrm{CM} 1202$ Perspect- $\mathrm{H}_{2} \mathrm{O}$ (Supramolecular photocatalytic water splitting).

Keywords: nickel $\cdot$ redox-active ligand $\cdot$ bioinspiration electrocatalyst $\cdot$ hydrogen evolution

[1] A. Borgschulte, Front. Energy Res. 2016, 4, 282-288

[2] O. T. Holton and J. W. Stevenson, Platinum Metals Review, 2013, 57, 259-271.

[3] J. R. McKone, S. C. Marinescu, B. S. Brunschwig, J. R. Winkler and H. B. Gray, Chem. Sci., 2014, 5, 865-878.

[4] V. S. Thoi, Y. J. Sun, J. R. Long and C. J. Chang, Chem. Soc. Rev., 2013, 42, 2388-2400.

[5] T. R. Simmons, G. Berggren, M. Bacchi, M. Fontecave and V. Artero, Coord. Chem. Rev., 2014, 270-271, 127-150

[6] N. Coutard, N. Kaeffer, V. Artero, Chem. Commun. 2016, DOI: 10.1039/c6cc06311j.

[7] W. Lubitz, H. Ogata, O. Rüdiger and E. Reijerse, Chem. Rev., 2014, 114, 4081-4148.

[8] D. Brazzolotto, M. Gennari, N. Queyriaux, T. R. Simmons, J. Pecaut, S. Demeshko, F. Meyer, M. Orio, V. Artero and C. Duboc, Nat. Chem. 2016, DOI:10.1038/nchem.2575.

[9] V. Artero, J.-M. Saveant, Energy Environ. Sci. 2014, 7, 3808-3814.

[10] D. L. DuBois, Inorg. Chem., 2014, 53, 3935-3960.
[11] N. Kaeffer, M. Chavarot-Kerlidou and V. Artero, Acc. Chem. Res., 2015, 48, 1286-1295.

[12] Eisenberg, R.; Gray, H. B. Inorg. Chem. 2011, 50, 9741-9751.

[13] Jurss, J. W.; Khnayzer, R. S.; Panetier, J. A.; El Roz, K. A.; Nichols, E. M.; Head-Gordon, M.; Long, J. R.; Castellano, F. N.; Chang, C. J. Chem. Sci. 2015, 6, 4954-4972.

[14] Thompson, E. J.; Berben, L. A. Angew. Chem. Int. Ed. 2015, 54 11642-11646.

[15] Haddad, A. Z.; Kumar, D.; Ouch Sampson, K.; Matzner, A. M.; Mashuta M. S.; Grapperhaus, C. A. J. Am. Chem. Soc. 2015, 137, 9238-9241.

[16] A. Z. Haddad, B. D. Garabato, P. M. Kozlowski, R. M. Buchanan, C. A Grapperhaus, J. Am. Chem. Soc. 2016, 138, 7844-7847.

[17] M. J. M. Campbell, Coord. Chem. Rev. 1975, 15, 279-317.

[18] B. M. Paterson and P. S. Donnelly, Chem. Soc. Rev. 2011, 40, 30053018

[19] E. J. T. L. A. Berben, Angew. Chem. Int. Ed. 2015, 54, 11642-11646.

[20] J. W. Jurss, R. S. Khnayzer, J. A. Panetier, K. A. El Roz, E. M. Nichols, M. Head-Gordon, J. R. Long, F. N. Castellano, C. J. Chang, Chem. Sci. 2015, 6, 4954-4972.

[21] E. Anxolabehere-Mallart, C. Costentin, M. Fournier, S. Nowak, M. Robert, J.-M. Savean, J. Am. Chem. Soc. 2012, 134, 6104-6107.

[22] V. Fourmond, S. Canaguier, B. Golly, M. J. Field, M. Fontecave, V. Artero, Energy Environ. Sci. 2011, 4, 2417-2427

[23] N. Elgrishi, M. B. Chambers, M. Fontecave, Chem. Sci. 2015, 6, 2522 2531

[24] V. Fourmond, P.A. Jacques, M. Fontecave and V. Artero Inorganic Chemistry, 2010, 49, 10338-10347

[25] C. Costentin, S. Drouet, M. Robert and J.-M. Savéant, J. Am. Chem. Soc., 2012, 134, 11235-11242.

[26] A. M. Demchenko, V. A. Yanchenko, V. V. Kisly, M. S. Lozinskii, Chemistry of Heterocyclic Compounds. 2005, 41, 668-672

[27] B. Lakshmi, P. G. Avaji, K. N. Shivananda, P. Nagella, S. H. Manohar, K. N. Mahendra, Polyhedron. 2011, 30, 1507-1515.

[28] S. Cobo, J. Heidkamp, P.-A. Jacques, J. Fize, V. Fourmond, L. Guetaz, B. Jousselme, V. Ivanova, H. Dau, S. Palacin, M. Fontecave and V. Artero, Nat. Mater., 2012, 11, 802-807.

[29] F. Neese, Wiley Interdiscip. Rev. Comput. Mol. Sci. 2012, 2, 73-78.

[30] a) J. P. Perdew, Phys. Rev. B 1986, 33, 8822-8824; b) J. P. Perdew, Phys. Rev. B 1986, 34, 7406-7406 ; c) A. D. Becke, Phys. Rev. A 1988, 38, 3098-3100

[31] A. Schäfer, C. Huber, R. Ahlrichs, J. Chem. Phys. 1994, 100, 5829 5835.

[32] F. Neese, J. Comput. Chem. 2003, 24, 1740-1747.

[33] F. Weigend, Phys. Chem. Chem. Phys. 2006, 8, 1057-1065.

[34] a) A. D. Becke, J. Chem. Phys. 1993, 98, 1372-1377; b) C. T. Lee, W.T. Yang, R. G. Parr, Phys. Rev. B 1988, 37, 785-789.

[35] A. Klamt, G. Schürmann, J. Chem. Soc. Perkin Trans. 2 1993, 799-805.

[36] a) M. E. Casida in Recent Advances in Density Functional Theory, Part I (Ed.: D. P. Chong), World Scientific, Singapore, 1995; b) R. E. Stratmann, G.E. Scuseria, M.J. Frisch, J. Chem. Phys. 1998, 109 8218-8224; c) R. Bauernschmitt, R. Ahlrichs, Chem. Phys. Lett. 1996 256, 454-464

[37] a) S. Hirata, M. Head-Gordon, Chem. Phys. Lett. 1999, 314, 291-299 b) S. Hirata, M. Head-Gordon, Chem. Phys. Lett. 1999, 302, 375-382.

[38] F. Neese, J. Chem. Phys. 2001, 115, 11080-11080.

[39] Chemcraft, http://chemcraftprog.com 


\section{FULL PAPER}

A mononuclear nickel complex NiL based on a thiosemicarbazone ligand is an efficient electrocatalyst for $\mathrm{H}_{2}$ evolution in DMF. With a maximum turnover frequency of $3080 \mathrm{~s}^{-1}$, it ranks among the best molecular $\mathrm{H}_{2}-$ evolving catalysts in catalytic Tafel plot. The catalytic mechanism involves ligand-based reduction and protonation steps followed by metalcentered processes.

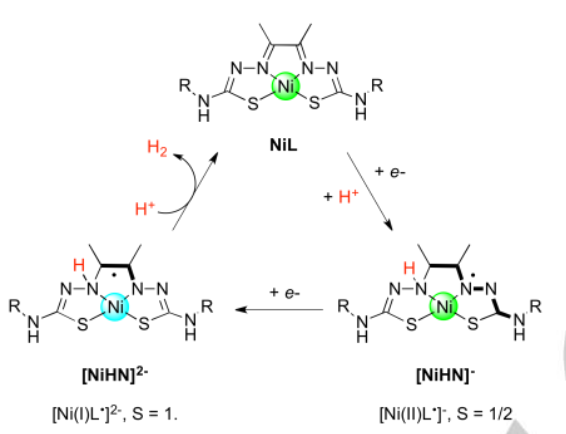

T. Straistari, J. Fize, S. Shova,

M. Réglier, V. Artero*, M. Orio*

Page No. - Page No.

Title

Ni(II) Ni(I) 